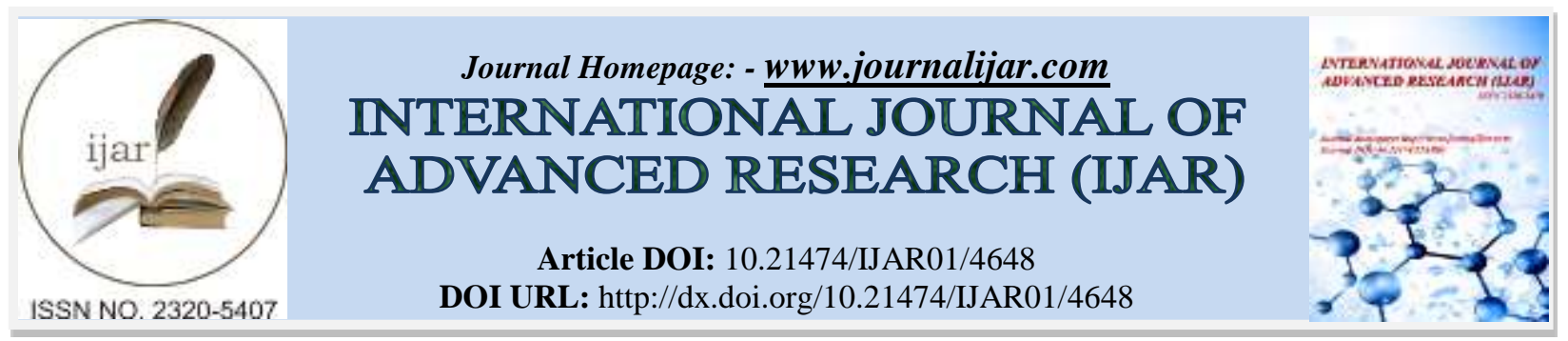

RESEARCH ARTICLE

\title{
STUDY TO ASSESS THE KNOWLEDGE AND ATTITUDE REGARDING PLAY NEEDS OF CHILDREN AMONG PARENTS OF VARIOUS ECONOMIC GROUPS.
}

Madan Mohan Gupta.

Assistant Professor, Teerthanker Mahaveer College of Nursing, Moradabad.

\section{Manuscript Info}

\section{Manuscript History}

Received: 19 April 2017

Final Accepted: 24 May 2017

Published: June 2017

Key words:-

Knowledge, Attitude, Parents, Economic

Groups, Play Needs

Children

\section{Abstract}

The study was conducted to assess the knowledge and attitude regarding Play Needs of Children among Parents of Various Economic Groups in Selected Areas of Dholpur Dist., Rajasthan.

A survey approach and descriptive explorative research design was adopted for study. For data was collected using purposive sampling technique among 90 parents who having children up to age of 5 years?

A structured interview schedule was used to assess the knowledge of parents regarding the play needs of children and modified 5 point Likert Scale was used to assess the attitude of parents. The collected data analyses using descriptive and inferential statistics.

The results of study revealed majority of samples 47 (52 percent) had inadequate knowledge regarding play needs. The overall mean knowledge score was 12.10 . Majority of samples 55 (61.1 percent) had favorable attitude towards play needs of children. The overall mean attitude score was 77.62.

There was no significant association found between the knowledge level of samples and demographic variables at $p<0.05$ level.

There was no significant association found between attitude level of samples and the variables at $\mathrm{p}<0.05$ level.

There was no significant association of knowledge with selected variables and also there was no significant association of attitude with selected variables

Background of study:-

Play helps the child to grow, develop, learn and ultimately mature. Parents are child's first and best play mates. The most creative children are those who have had parents involved in their play. Therefore parents must have adequate knowledge and attitude towards the play needs of their children. This study was conducted to assess and correlate parent's knowledge and attitude regarding play needs of children and to associate knowledge and attitude with selected demographic variables. 


\section{Need of study:-}

"Many of the things we need can wait. The child cannot. His name is today. To him we cannot answer tomorrow" Gabriela Mistal

All children need to play irrespective of age, culture, and social background, economic circumstances. Parents must know the play needs of their children to maintain sound mental and physical health. Babies and toddlers need a safe, healthy environment and warm, responsive adults to stimulate their growth and development. It is nature and nurture' working together that enhances physical, social, emotional, cognitive, cultural and creative growth in children

The investigator is intended to assess the knowledge and attitude of parents of different economic group towards the play needs of their children of 0-3 age group. There are limitations, failures occur in all these groups, and the corrective measures may be based on best judgment and/or practices or from the previous data available from some other studies. Due to these limitations, failures in meeting the play needs of children, they end up with delayed or poor physical and intellectual development. In India, the researcher could find very few studies regarding play needs of children. As a nurse, the researcher has a pivotal role in recognizing these concerns and implementing measures to understand the value of the play needs, development of social forms of play behavior, characteristic of play, sex role behavior in play, selection and care of play things to the parents

\section{Objectives of study:-}

1. To assess the knowledge and attitude of parents of various economic groups regarding the play needs of children.

2. To identify the correlation between the knowledge and attitude of parents of various economic group regarding the play needs of children.

3. To find out the association of knowledge and attitude of parents of various economic group towards the play needs of their children with selected demographic variables.

Variables of study:-

Research variables: - Knowledge and attitude

Demographic variables:- Age, gender, type of the family, education, occupation, income, religion, no of children and age $\&$ sex of children.

Conceptual framework:- Conceptual Framework of knowledge and attitude of parents regarding play needs of children base on Barnard's parents-child interaction model.

\section{Method and Material:-}

Research approach: - Survey approach was adopted for this study

Research design:- A descriptive research was found to be most appropriate for this study

Research setting:- The present study was undertaken in Baseri, Dholpur Dist, Rajasthan due to the geographical proximity, feasibility of the study and availability of the sample.

\section{Population:-}

Target population: - The target population for the present study comprised of parents of various income groups having children of birth to 5 years of age residing in Baseri, Dholpur Dist, Rajasthan.

Sample:-. In this study the sample consisted of parents of various income groups having children of birth to 5 years of age residing in Baseri, Dholpur Dist, Rajasthan.

Sample size:- sample size of 90 parents of various income groups having children of birth to 5 years of age and fulfill the exclusion and inclusion criteria.

Sampling technique:- Purposive sampling technique

Inclusion criteria:- Parents who are willing to participate, Parents who are having children of birth to 5 years \& Parents in the age group of 21-50 years 
Exclusion criteria: - Single parent, Parents with children of physically or mentally challenged \& Parents with children of terminal illness

\section{Method of Data Collection:-}

Tool for data collection: - The following tools were used for the study:

1. Structured interview schedule to assess the knowledge of parents towards play needs of children.

2. Five point scale to assess the attitude of parents regarding play needs of children of birth to 5 years age.

The tool consists of three parts, part I, II and III

Part - I: demographic Data:- This section consisted of 9 items seeking personal information such as age, gender, type of family, religion, characteristics of the subjects such as educational qualification, income and occupation, number of children, their age and gender. The samples were requested to answer for the data.

Part -II: structured interview schedule: - The structured interview schedule consisted of 25 items on knowledge about play needs of children -meaning importance, types of play in different age groups, functions of play, selection of play materials \& safety. Each question had 4 responses with which one correct response and 3 distracters. Score ' 1 ' was given for correct response in a single question and score ' 0 ' was given for wrong response. The total number of responses was twenty five giving rise to maximum score of 25 .

\section{The resulting score were ranged as follows:-}

Adequate: more than $75 \%$ (19-25 marks)

Moderately adequate: $50-75 \%$ (13-18 marks)

Inadequate: less than $50 \%$ (less than 13 marks)

Part- III: Modified form of 5 point Likert scale prepared with attitude statement regarding play needs of children. It consisted of 20 statements and 5 columns such as Strongly Agree (SA), Agree (A), Uncertain (UC), Disagree (D) and Strongly Disagree (SD).There were 10 negative and 10 positive statements. Each positive statement carried the score 5, 4,3,2,1 and negative carried the score 1,2,3,4,5. The resulting score were ranged as follows

Favorable: more than $75 \%$ (75-100 marks)

Moderately favorable: 50 - 75\% (50-74 marks)

Unfavorable: less than 50\% (less than 50 marks)

\section{Development of tool:-}

The tool was developed by using the following steps

- Extensive review of research literature

- Consultation with experts

- Establishing content of validity by formally seeking the suggestion and recommendations of experts

- Establishing reliability of tool by applying statistical procedures

- Pilot study

- Main study

\section{Reliability:-}

In order to establish the reliability of the tool, split- half method was used. Tool administered to 12 samples and the test was first divided into 2 equal halves and correlation of the half test was found by using Karl Pearson correlation coefficient formula and significance of the correlation was tested by using probable error. The reliability of the whole test was then estimated by Spearman's brown prophecy formula. The reliability of the interview schedule to assess knowledge was found to be 0.8753 , and the reliability of the attitude scale was found to be 0.8842 . Hence the tool was found to be reliable.

\section{Data collection procedure:-}

The data collection was done for 4 weeks in Baseri, Dholpur Dist, Rajasthan. A written permission was obtained from the concern authority. Data were collected from 90 parents who fulfilled the inclusion and exclusion criteria. After brief introduction of self and study, a written consent of the participant was sought. The investigator interviewed the samples. Data collection took 20 to 30 minutes for each sample. The investigator expressed thanks 
to the samples thus data collection was terminated. The purpose of the study was explained and informed Consent obtained. The analysis was done by using descriptive and inferential statistics.

\section{Study findings -}

The data were presented under the following sections

The data collected were organized and presented under the following sections

Section A: Distribution of samples based on demographic characteristics

Section B: Knowledge of the samples towards play needs of children of birth to 5 years of age group.

Section C: Attitude of samples towards play needs of children of birth to 5 years of age group.

Section D: Correlation of knowledge score with the attitude score

Section E: Association of knowledge scores with selected demographic variables.

Section F: Association of attitude scores with selected demographic variables

\section{Section A: Distribution of samples based on demographic characteristics:-}

In the present study observed that, $9(30 \%), 12(40 \%), 9(30 \%)$ of the low income groups were in the age group of 21-30 years, 31-40 years, 41-50 years respectively. $5(16.7 \%), 24(80 \%), 1(3.3 \%)$ of middle income group were in the age group of 21-30 years, 31-40 years, 41-50 years respectively. 5 (16.75\%), $20(66.75 \%), 5$ (16.6\%) of high income group were in the age group of 21-30 years, 31-40 years, $41-50$ years respectively.

In the present study observed that 4(13.3\%) samples of low income group, 11(36.7\%) samples of middle group, 16 (53.3\%) samples of high income group were males and 26 (86.7\%) samples of low income group, 19(63.3\%) sample of middle income group, $14(46.7 \%)$ samples of high income group were females.

In the present study observed that,18 (60\%) samples of low income group, $22(73.4 \%)$ samples of middle income group, $23(76.7 \%)$ samples of high income group belonged to nuclear family. $5(16.7 \%)$. samples of low income group, 7 (23.3\%) samples of middle income group, 4 (13.3\%) samples of high income group belonged to joint family. $7(23.3 \%)$ samples of low income group, 1 (3.3\%) samples of middle income group, $3(10.0 \%)$ samples of high income group belonged to extended family.

28 (93.3\%) samples of low income group, 15 (50\%) samples of middle income group, 23 (76.6\%) of high income group belonged to Hindu religion. 2 (6.67\%) samples of low income group, $6(20 \%)$ of middle income group, 5 (16.7\%) of high income group belonged to Muslim religion. 0 (0\%) of low income group, 9 (30\%) of middle income group, 2 (6.67\%) of high income group belonged to Christian religion.

19(63.4\%) samples of low income group, 9 (30\% ) samples of middle income group, 21 (70\%) of high income group had one child each. 10 (33.3\%) samples of low income group, 21 (70\%) of middle income group, 7 (23.3\%) of high income group had two children each.1 (3.3\%) of low income group, $0(0 \%)$ of middle income group, 2 (6.7\%) of high income group had 3 children each.

The present study revealed that $15(50 \%)$ samples of low income group, $13(43.3 \%)$ of middle income group, 11 (37.7\%) samples of high income group had children less than 2 years of age. $18(60 \%)$ of low income group, 24 (80\%) of middle income group, 21 (70\%) of high income group have children of $2-3$ years. 3 (10\% of low income group, $9(30 \%)$ of middle income group, 1 (3.3\%) of high income group had children of $4-5$ years.6 (20\%) of low income group, $5(16.7 \%)$ of middle income group, $9(30 \%)$ of high income group had children more than 5 years of age group.

Present study revealed $23(76.7 \%)$ samples of low income group, $23(76.7 \%)$ of middle income group, 22 (73.3\%) of high income group had male children. 19 (63.3\% ) samples of low income group, $28(93.3 \%)$ of middle income group , $20(66.7 \%)$ of high income group had female children.

The present study revealed 4 (4.4\%) of fathers and $26(28.9 \%)$ of mothers were below matriculation.28 (31.1\%) fathers and 12 (13.35) mothers were matriculates. 12 (13.3\%) father and $7(7.8 \%)$ mother were intermediate. 23 (25.6\%) father and $29(32.2 \%)$ mother were graduate. $23(25.6 \%)$ fathers and $16(17.8 \%)$ mothers were postgraduate. 
Present study revealed that $20(22.2 \%)$ fathers and $0(0 \%)$ mothers were coolie workers. $0(0 \%)$ fathers and 59 (65.6) mothers were housewives. $16(17.8 \%)$ fathers and $0(0 \%)$ mothers were business people. $40(44.4 \%)$ fathers and $19(21.1 \%)$ mothers were private firm employees. $14(15.6 \%)$ fathers and $12(13.3 \%)$ mothers were government employees.

Section B:- Knowledge of the samples towards play needs of children of birth to 5 years of age group:-

Table 1:- Mean knowledge of samples of different economic groups

\begin{tabular}{|c|c|c|c|c|c|c|}
\hline \multirow[t]{2}{*}{ Income group } & \multirow{2}{*}{$\begin{array}{c}\text { Sample } \\
\text { (n) }\end{array}$} & \multirow[t]{2}{*}{ Score } & \multirow{2}{*}{$\begin{array}{l}\text { Range } \\
\text { Score }\end{array}$} & \multicolumn{3}{|c|}{ Knowledge } \\
\hline & & & & Mean & Mean (\%) & SD \\
\hline Low & 30 & 25 & $5-17$ & 9.93 & 39.7 & 3.2 \\
\hline Middle & 30 & 25 & $6-18$ & 12.40 & 49.6 & 3.6 \\
\hline High & 30 & 25 & $8-17$ & 13.97 & 55.9 & 2.3 \\
\hline combined & 90 & 25 & $5-18$ & 12.10 & 48.4 & 3.5 \\
\hline
\end{tabular}

The mean knowledge of low income group, middle income group and high income group was 9.93, 12.4, 13.97 respectively. Corresponding standard deviations were 3.2, 3.6, and 2.3 respectively. The overall mean knowledge was 12.10 with standard deviation 3.5 .

Table 2:- Knowledge level of the samples of different economic group

$\mathrm{n}=90$

\begin{tabular}{|c|c|c|c|c|c|c|c|c|}
\hline \multirow{2}{*}{ Level } & \multicolumn{9}{c|}{ Respondents by Income Groups } \\
\cline { 2 - 10 } & \multicolumn{2}{|c|}{ Low } & \multicolumn{2}{c|}{ Middle } & \multicolumn{3}{c|}{ High } & \multicolumn{2}{c|}{ Total } \\
\cline { 2 - 10 } & $\mathrm{n}$ & $\%$ & $\mathrm{n}$ & $\%$ & $\mathrm{n}$ & $\%$ & $\mathrm{n}$ & $\%$ \\
\hline Inadequate & 25 & 83.3 & 16 & 53.3 & 6 & 20.0 & 47 & 52.2 \\
\hline Moderately Inadequate & 5 & 16.7 & 14 & 46.7 & 24 & 80.0 & 43 & 47.8 \\
\hline Total=30 & 30 & 100.0 & 30 & 100.0 & 30 & 100.0 & 90 & 100.0 \\
\hline
\end{tabular}

Out of 90 samples, $47(52 \%)$ had inadequate knowledge, 43 (47.8\%) had moderately adequate knowledge and none of them had adequate knowledge on play needs of children of birth to 5 years of age group.

Section C: Attitude of samples towards play needs of children of birth to 5 years of age group.

Table 3:- Mean attitude of samples of different economic groups $\quad n=90$

\begin{tabular}{|c|c|c|c|c|c|c|}
\hline $\begin{array}{c}\text { Income } \\
\text { group }\end{array}$ & $\begin{array}{c}\text { Sample } \\
(\mathbf{n})\end{array}$ & Score & Range Score & \multicolumn{3}{|c|}{ Respondent Attitude } \\
\cline { 4 - 7 } & & & Mean & Mean (\%) & SD \\
\hline Low & 30 & 100 & $32-91$ & 72.53 & 72.5 & 14.9 \\
\hline Middle & 30 & 100 & $51-91$ & 78.40 & 78.4 & 10.1 \\
\hline High & 30 & 100 & $61-91$ & 81.93 & 81.9 & 9.5 \\
\hline combined & 90 & 100 & $32-91$ & 77.62 & 77.6 & 12.3 \\
\hline
\end{tabular}

The mean attitude of low income group, middle income group and high income group was 72.53, 78.40, 81.93 respectively. Corresponding standard deviations were 14.9, 10.1 and 9.5 respectively. The overall mean attitude was 77.62 with standard deviation 12.3 .

Table 4:- Attitude level of samples of different economic groups $\quad \mathrm{n}=90$

\begin{tabular}{|l|c|c|c|c|c|c|c|c|}
\hline \multirow{3}{*}{\begin{tabular}{c}
\multirow{4}{*}{$\begin{array}{c}\text { Attitude } \\
\text { level }\end{array}$} \\
\cline { 2 - 10 }
\end{tabular}} & \multicolumn{2}{|c|}{ Low } & \multicolumn{2}{c|}{ High } & \multicolumn{2}{c|}{ Middle } & \multicolumn{2}{c|}{ Total } \\
\hline $\begin{array}{l}\text { Moderately } \\
\text { favourable }\end{array}$ & 15 & 50.0 & 9 & 30.0 & 11 & 36.7 & 35 & 38.9 \\
\hline Favourable & 15 & 50.0 & 21 & 7.0 & 19 & 63.3 & 55 & 61.1 \\
\hline Total & 30 & 100.0 & 30 & 100.0 & 30 & 100.0 & 90 & 100.0 \\
\hline
\end{tabular}

Out of 90 samples, 35(38.9\%) had moderately favourable attitude, 55 (61.1\%) had favourable attitude and none of them had unfavourable attitude towards the play needs of the children. 
Section D: Correlation of the knowledge score with the attitude score.

Table 5:- Correlation between knowledge and attitude of samples

\begin{tabular}{|c|c|c|}
\hline Income group & Sample size $(\mathrm{n})$ & $\begin{array}{c}\text { Correlation coefficient (r) between } \\
\text { Knowledge and Attitude }\end{array}$ \\
\hline Low Income & 30 & +0.418 \\
\hline Middle Income & 30 & +0.253 \\
\hline High Income & 30 & +0.463 \\
\hline Combined & 90 & +0.453 \\
\hline
\end{tabular}

The correlation between the knowledge and attitude of parents of low income, middle income and high income were $+0.418,+0.253$ and +0.463 respectively. Findings of the study revealed a positive correlation between knowledge and attitude of parents of different economic groups regarding play needs of children of birth to 5 years of age group. This correlation between knowledge and attitude indicates that parents with good knowledge on play needs of their children have a favourable attitude towards it.

Section E:- Association of knowledge scores with selected demographic variables.

Table 6:- Association between knowledge score of the parents of various economic group regarding play needs with selected demographic variables $\mathrm{n}=90$.

\begin{tabular}{|c|c|c|c|c|c|c|c|c|}
\hline \multirow{3}{*}{ Knowledge level } & \multicolumn{8}{|c|}{ Respondents By Income Group } \\
\hline & \multicolumn{2}{|c|}{ Low } & \multicolumn{2}{|c|}{ Middle } & \multicolumn{2}{|c|}{ High } & \multicolumn{2}{|c|}{ Total } \\
\hline & $\mathrm{n}$ & $\%$ & $\mathrm{n}$ & $\%$ & $\mathrm{n}$ & $\%$ & $\mathrm{n}$ & $\%$ \\
\hline Inadequate & 25 & 83.3 & 16 & 53.3 & 6 & 20.0 & 47 & 52.2 \\
\hline $\begin{array}{l}\text { Moderately } \\
\text { Adequate }\end{array}$ & 5 & 16.7 & 14 & 46.7 & 24 & 80.0 & 43 & 47.8 \\
\hline Total & 30 & 100.0 & 30 & 100.0 & 30 & 100.0 & 90 & 100.0 \\
\hline $\mathrm{X}^{2}$ Value & & & & 4* & & & & \\
\hline
\end{tabular}

* Significant at $5 \%$ level $\mathrm{X}^{2}(0.05,4 \mathrm{df})=9.488$

The study observed there was a significant association found between knowledge of parents of various economic group towards the play needs of children with the selected demographic variable at $\mathrm{p}<0.05$ level.

Table 7:- Association between knowledge score of the parents various economic group regarding play needs with selected demographic variables like age, sex, type of family education of mother\& occupation of father. $n=90$

\begin{tabular}{|c|c|c|c|c|c|c|c|c|c|}
\hline \multirow{3}{*}{ Demographic Data } & \multicolumn{6}{|c|}{ Knowledge Level } & \multirow{3}{*}{$\begin{array}{l}\mathbf{X}^{2} \\
\text { Value }\end{array}$} & \multirow{3}{*}{ Df } & \multirow[t]{3}{*}{$\mathbf{t}$} \\
\hline & \multicolumn{2}{|c|}{ Inadequate } & \multicolumn{2}{|c|}{ Moderate } & \multicolumn{2}{|c|}{ Total } & & & \\
\hline & $\mathbf{n}$ & $\%$ & $\mathbf{N}$ & $\%$ & $\mathbf{n}$ & $\%$ & & & \\
\hline \multicolumn{10}{|l|}{ Age Group (in years) } \\
\hline $21-30$ & 10 & 52.6 & 09 & 47.4 & 19 & 100 & \multirow{3}{*}{$6.93^{*}$} & \multirow{3}{*}{2} & \multirow{3}{*}{5.991} \\
\hline $31-40$ & 24 & 44.6 & 31 & 55.4 & 56 & 100 & & & \\
\hline $41-50$ & 12 & 80 & 03 & 20 & 15 & 100 & & & \\
\hline Combined & 47 & 52.2 & 43 & 41.8 & 90 & 100 & & & \\
\hline \multicolumn{10}{|l|}{ Sex } \\
\hline Male & 11 & 35.5 & 20 & 64.5 & 31 & 100 & \multirow{2}{*}{$5.31 *$} & \multirow[t]{2}{*}{1} & \multirow{2}{*}{3.841} \\
\hline Female & 36 & 61 & 23 & 39 & 59 & 100 & & & \\
\hline Combined & 47 & 52.2 & 43 & 41.8 & 90 & 100 & & & \\
\hline \multicolumn{10}{|l|}{ Type Of Family } \\
\hline Nuclear & 28 & 44.4 & 35 & 55.6 & 63 & 100 & \multirow{3}{*}{$6.43^{*}$} & \multirow{3}{*}{2} & \multirow{3}{*}{5.991} \\
\hline Joint & 12 & 75 & 04 & 25 & 16 & 100 & & & \\
\hline Extended & 07 & 63.6 & 04 & 36.4 & 11 & 100 & & & \\
\hline Combined & 47 & 52.2 & 43 & 41.8 & 90 & 100 & & & \\
\hline \multicolumn{10}{|l|}{ Education Of Mother } \\
\hline Below Matriculation & 21 & 80.8 & 05 & 19.2 & 26 & 100 & \multirow{5}{*}{$19.12 *$} & \multirow{5}{*}{4} & \multirow{5}{*}{9.488} \\
\hline Matriculation & 08 & 66.7 & 04 & 33.3 & 12 & 100 & & & \\
\hline Intermediate & 04 & 57.1 & 03 & 42.9 & 07 & 100 & & & \\
\hline Graduate & 11 & 37.9 & 18 & 62.1 & 29 & 100 & & & \\
\hline Post graduate & 03 & 18.7 & 13 & 81.3 & 16 & 100 & & & \\
\hline
\end{tabular}




\begin{tabular}{|c|c|c|c|c|c|c|c|c|c|}
\hline Combined & 47 & 52.2 & 43 & 41.8 & 90 & 100 & & & \\
\hline Occupation & & & & & & & & & \\
\hline Coolie & 16 & 80 & 04 & 20 & 20 & 100 & \multirow{4}{*}{$8.19 *$} & \multirow{4}{*}{3} & \multirow{4}{*}{7.815} \\
\hline Business & 07 & 43.8 & 09 & 56.2 & 16 & 100 & & & \\
\hline Private & 17 & 42.5 & 23 & 57.5 & 40 & 100 & & & \\
\hline Government & 07 & 50 & 07 & 50 & 14 & 100 & & & \\
\hline Combined & 47 & 52.2 & 43 & 41.8 & 90 & 100 & & & \\
\hline
\end{tabular}

* Significant at $5 \%$ level

There was a significant association found between knowledge and age of the parents. $\left(X^{2}=6.93\right.$ at $\mathrm{p}<0.05$ level), knowledge and gender $\left(X^{2}=5.31\right.$ at $\mathrm{p}<0.05$ level $)$, knowledge and type of family $(X=6.43$ at $\mathrm{p}<0.05$ level $)$, knowledge and education of mother $\left(X^{2}=19.12\right.$ at $\mathrm{p}<0.05$ level), knowledge and occupation of father $\left(X^{2}=8.19\right.$ at $p<0.05$ level $)$, knowledge and occupation of mother $\left(X^{2}=18.24\right.$ at $p<0.05$ level $)$

NS:-Non Significant

Table 8:- Association between knowledge score of the parents various economic group regarding play needs with selected demographic variables like religion, number of children sex of the child education of the father. $\quad n=90$

\begin{tabular}{|c|c|c|c|c|c|c|c|c|c|}
\hline \multirow{3}{*}{$\begin{array}{c}\text { Demographic } \\
\text { Data }\end{array}$} & \multicolumn{6}{|c|}{ Knowledge Level } & \multirow{3}{*}{$\begin{array}{c}\mathbf{X}^{2} \\
\text { Value }\end{array}$} & \multirow[t]{3}{*}{ Df } & \multirow[t]{3}{*}{$\mathbf{t}$} \\
\hline & \multicolumn{2}{|c|}{ Inadequate } & \multicolumn{2}{|c|}{ Moderate } & \multicolumn{2}{|c|}{ Total } & & & \\
\hline & $\mathbf{n}$ & $\%$ & $\mathbf{N}$ & $\%$ & $\mathbf{n}$ & $\%$ & & & \\
\hline \multicolumn{10}{|l|}{ Religion } \\
\hline Hindu & 33 & 50 & 33 & 50 & 66 & 100 & \multirow{3}{*}{$4.42^{\mathrm{NS}}$} & \multirow{3}{*}{2} & \multirow{3}{*}{5.991} \\
\hline Muslim & 10 & 76.9 & 03 & 23.1 & 13 & 100 & & & \\
\hline Christian & 04 & 36.4 & 07 & 63.4 & 11 & 100 & & & \\
\hline Combined & 47 & 52.2 & 43 & 41.8 & 90 & 100 & & & \\
\hline \multicolumn{10}{|l|}{ No. of children } \\
\hline One & 24 & 49 & 25 & 51 & 49 & 100 & \multirow{3}{*}{$2.95^{\mathrm{NS}}$} & \multirow{3}{*}{2} & \multirow{3}{*}{5.991} \\
\hline Two & 20 & 52.6 & 18 & 47.4 & 38 & 100 & & & \\
\hline Three & 03 & 100 & 00 & 00 & 03 & 100 & & & \\
\hline Combined & 47 & 52.2 & 43 & 41.8 & 90 & 100 & & & \\
\hline \multicolumn{10}{|l|}{ Sex of the child } \\
\hline Male & 13 & 46.4 & 15 & 53.6 & 28 & 100 & \multirow{3}{*}{$1.17^{\mathrm{NS}}$} & \multirow{3}{*}{2} & \multirow{3}{*}{5.991} \\
\hline Female & 18 & 60 & 12 & 40 & 30 & 100 & & & \\
\hline Both & 16 & 50 & 16 & 50 & 32 & 100 & & & \\
\hline Combined & 47 & 52.2 & 43 & 41.8 & 90 & 100 & & & \\
\hline \multicolumn{10}{|l|}{ Education Of Father } \\
\hline Below Matriculation & 02 & 50 & 02 & 50 & 04 & 100 & \multirow{5}{*}{$8.88^{\mathrm{NS}}$} & \multirow{5}{*}{4} & \multirow{5}{*}{9.448} \\
\hline Matriculation & 20 & 71.4 & 08 & 28.6 & 28 & 100 & & & \\
\hline Intermediate & 07 & 58.3 & 05 & 41.7 & 12 & 100 & & & \\
\hline Graduate & 11 & 47.8 & 12 & 52.2 & 23 & 100 & & & \\
\hline Post graduate & 07 & 30.4 & 16 & 69.6 & 23 & 100 & & & \\
\hline Combined & 47 & 52.2 & 43 & 41.8 & 90 & 100 & & & \\
\hline
\end{tabular}

There was a non-significant relation found between knowledge and religion ( $\mathrm{X} 2=4.42$ at $\mathrm{p}<0.05$ level), knowledge and number of children $(\mathrm{X} 2=2.95$ at $\mathrm{p}<0.05$ level $)$, knowledge and sex of child( $\mathrm{X} 2=1.17$ at $\mathrm{p}<0.05$ level $)$, knowledge and education of father $(\mathrm{X} 2=8.88$ at $\mathrm{p}<0.05$ level $)$. 
Section F:- Association of attitude scores with selected demographic variables. +

Table 9:- Association between Attitude of parents of various economic group and demographical variables $\quad \mathrm{n}=90$

\begin{tabular}{|l|c|c|c|c|c|c|c|c|}
\hline \multirow{2}{*}{ Attitude level } & \multicolumn{9}{|c|}{ Income Group } \\
\cline { 2 - 9 } & \multicolumn{2}{|c|}{ Low } & \multicolumn{2}{c|}{ Middle } & \multicolumn{2}{c|}{ High } & \multicolumn{2}{c|}{ Total } \\
\cline { 2 - 9 } & $\mathrm{n}$ & $\%$ & $\mathrm{n}$ & $\%$ & $\mathrm{n}$ & $\%$ & $\mathrm{n}$ & $\%$ \\
\hline $\begin{array}{l}\text { Moderately } \\
\text { favourable }\end{array}$ & 15 & 50.0 & 11 & 36.7 & 09 & 30.0 & 35 & 38.9 \\
\hline Favourabl & 15 & 50.0 & 19 & 63.3 & 21 & 70.0 & 55 & 61.1 \\
\hline Total & 30 & 100.0 & 30 & 100.0 & 30 & 100.0 & 90 & 100.0 \\
\hline$X^{2}$ Value & \multicolumn{7}{|c|}{2.62} \\
\hline
\end{tabular}

NS: Non-Significant

$\mathrm{X}^{2}(0.05,2 \mathrm{df})=$

5.991

Table 10:- Association between Attitude and Variables like education of mother \& occupation of mother $n=90$

\begin{tabular}{|c|c|c|c|c|c|c|c|c|c|}
\hline \multirow{3}{*}{$\begin{array}{c}\text { Demographic } \\
\text { Data }\end{array}$} & \multicolumn{6}{|c|}{ Attitude Level } & \multirow{3}{*}{$\begin{array}{c}\mathbf{X}^{2} \\
\text { Value }\end{array}$} & \multirow[t]{3}{*}{ df } & \multirow[t]{3}{*}{$\mathbf{T}$} \\
\hline & \multicolumn{2}{|c|}{ Moderate } & \multicolumn{2}{|c|}{ Favourable } & \multicolumn{2}{|c|}{ Total } & & & \\
\hline & $\mathbf{n}$ & $\%$ & $\mathbf{n}$ & $\%$ & $\mathbf{n}$ & $\%$ & & & \\
\hline Education Of Mother & & & & & & & \multirow{6}{*}{$11.14 *$} & \multirow{6}{*}{4} & \multirow{6}{*}{9.488} \\
\hline Below Matriculation & 15 & 57.7 & 11 & 42.3 & 26 & 100.0 & & & \\
\hline Matriculation & 05 & 41.7 & 07 & 58.3 & 12 & 100.0 & & & \\
\hline Intermediate & 03 & 42.9 & 04 & 47.1 & 07 & 100.0 & & & \\
\hline Graduate & 11 & 37.9 & 18 & 62.1 & 29 & 100.0 & & & \\
\hline Post graduate & 01 & 6.2 & 15 & 93.8 & 16 & 100.0 & & & \\
\hline Combined & 35 & 38.9 & 55 & 61.1 & 90 & 100.0 & & & \\
\hline \multicolumn{10}{|l|}{ Occupation Of Mother } \\
\hline House wife & 29 & 49.2 & 30 & 50.8 & 59 & 100.0 & \multirow{3}{*}{$7.65 *$} & \multirow{3}{*}{2} & \multirow{3}{*}{5.991} \\
\hline Private & 04 & 21.1 & 15 & 79.5 & 19 & 100.0 & & & \\
\hline Government & 02 & 16.7 & 10 & 83.3 & 12 & 100.0 & & & \\
\hline Combined & 35 & 38.9 & 55 & 61.1 & 90 & 100.0 & & & \\
\hline
\end{tabular}

Present study revealed there was no significant association between the attitude and income groups of the samples.

* Significant at $5 \%$ level,

Table 11:- Association between attitude and variables like age, sex, type of family, religion, number of children, sex of the child \& education and occupation of father. $\mathrm{n}=90$.

\begin{tabular}{|c|c|c|c|c|c|c|c|c|c|}
\hline \multirow{3}{*}{$\begin{array}{c}\text { DEMOGRAPHIC } \\
\text { DATA }\end{array}$} & \multicolumn{6}{|c|}{ Attitude Level } & \multirow{3}{*}{$\begin{array}{c}\mathrm{X}^{2} \\
\text { Value }\end{array}$} & \multirow[t]{3}{*}{ Df } & \multirow[t]{3}{*}{$\mathbf{T}$} \\
\hline & \multicolumn{2}{|c|}{ Moderate } & \multicolumn{2}{|c|}{ Favourable } & \multicolumn{2}{|c|}{ Total } & & & \\
\hline & $\mathbf{n}$ & $\%$ & $\mathbf{n}$ & $\%$ & $\mathbf{n}$ & $\%$ & & & \\
\hline \multicolumn{10}{|l|}{ Age Group (in years) } \\
\hline $21-30$ & 07 & 36.8 & 12 & 63.2 & 19 & 100 & \multirow{3}{*}{$1.59^{\mathrm{NS}}$} & \multirow{3}{*}{2} & \multirow{3}{*}{5.991} \\
\hline $31-40$ & 20 & 35.7 & 36 & 64.3 & 56 & 100 & & & \\
\hline $41-50$ & 08 & 53.3 & 07 & 46.7 & 15 & 100 & & & \\
\hline Combined & 35 & 38.9 & 55 & 61.1 & 90 & 100 & & & \\
\hline \multicolumn{10}{|l|}{ Sex } \\
\hline Male & 10 & 32.3 & 21 & 67.7 & 31 & 100 & \multirow[b]{2}{*}{$0.88^{\mathrm{NS}}$} & \multirow{2}{*}{1} & \multirow{3}{*}{3.841} \\
\hline Female & 25 & 42.4 & 34 & 57.6 & 59 & 100 & & & \\
\hline Combined & 35 & 38.9 & 55 & 61.1 & 90 & 100 & & & \\
\hline \multicolumn{10}{|l|}{ Type Of Family } \\
\hline Nuclear & 23 & 36.5 & 40 & 63.5 & 63 & 100 & \multirow{3}{*}{$0.51^{\mathrm{NS}}$} & \multirow{3}{*}{2} & \multirow{3}{*}{5.991} \\
\hline Joint & 07 & 43.8 & 09 & 56.2 & 16 & 100 & & & \\
\hline Extended & 05 & 45.5 & 06 & 54.5 & 11 & 100 & & & \\
\hline Combined & 35 & 38.9 & 55 & 61.1 & 90 & 100 & & & \\
\hline \multicolumn{10}{|l|}{ Religion } \\
\hline Hindu & 25 & 37.9 & 41 & 62.1 & 66 & 100 & & & \\
\hline
\end{tabular}




\begin{tabular}{|c|c|c|c|c|c|c|c|c|c|}
\hline Muslim & 06 & 46.2 & 07 & 53.8 & 13 & 100 & \multirow[t]{2}{*}{$0.35^{\mathrm{NS}}$} & \multirow[t]{2}{*}{2} & \multirow[t]{2}{*}{5.991} \\
\hline Christian & 04 & 36.4 & 07 & 63.6 & 11 & 100 & & & \\
\hline Combined & 35 & 38.9 & 55 & 61.1 & 90 & 100 & & & \\
\hline \multicolumn{10}{|l|}{ No. of children } \\
\hline One & 16 & 32.7 & 33 & 67.3 & 49 & 100 & \multirow{3}{*}{2.32} & \multirow{3}{*}{2} & \multirow{3}{*}{5.991} \\
\hline Two & 17 & 44.7 & 21 & 55.3 & 38 & 100 & & & \\
\hline Three & 02 & 66.7 & 01 & 33.3 & 03 & 100 & & & \\
\hline Combined & 35 & 38.9 & 55 & 61.1 & 90 & 100 & & & \\
\hline \multicolumn{10}{|l|}{ Sex of the child } \\
\hline Male & 08 & 28.6 & 20 & 71.4 & 28 & 100 & \multirow{3}{*}{$2^{\mathrm{NS}}$} & \multirow{3}{*}{2.06} & \multirow{3}{*}{5.991} \\
\hline Female & 14 & 46.7 & 16 & 53.3 & 30 & 100 & & & \\
\hline Both & 13 & 40.6 & 19 & 59.4 & 32 & 100 & & & \\
\hline Combined & 35 & 38.9 & 55 & 61.1 & 90 & 100 & & & \\
\hline \multicolumn{10}{|l|}{ Education Of Father } \\
\hline Below Matriculation & 02 & 50 & 02 & 50 & 04 & 100 & \multirow{5}{*}{$2.82^{\mathrm{NS}}$} & \multirow{5}{*}{4} & \multirow{5}{*}{9.488} \\
\hline Matriculation & 13 & 46.4 & 15 & 53.6 & 28 & 100 & & & \\
\hline Intermediate & 04 & 33.3 & 08 & 66.7 & 12 & 100 & & & \\
\hline Graduate & 10 & 43.5 & 13 & 56.7 & 23 & 100 & & & \\
\hline Post graduate & 06 & 26.1 & 17 & 73.9 & 23 & 100 & & & \\
\hline Combined & 35 & 38.9 & 55 & 61.1 & 90 & 100 & & & \\
\hline \multicolumn{10}{|l|}{ Occupation Of Father } \\
\hline Coolie & 11 & 55 & 09 & 45 & 20 & 100 & \multirow{4}{*}{$3.62^{\mathrm{NS}}$} & \multirow{4}{*}{3} & \multirow{4}{*}{7.815} \\
\hline Business & 06 & 37.5 & 10 & 62.5 & 16 & 100 & & & \\
\hline Private & 12 & 30 & 28 & 70 & 40 & 100 & & & \\
\hline Government & 06 & 42.9 & 08 & 57.1 & 14 & 100 & & & \\
\hline Combined & 35 & 38.9 & 55 & 61.1 & 90 & 100 & & & \\
\hline
\end{tabular}

There was a significant association found between the attitude and education of mother $(\mathrm{X} 2=11.14$ at $\mathrm{p}<0.05$ level) and attitude and occupation of mother $(\mathrm{X} 2=7.65$ at $\mathrm{p}<0.05$ level).

NS: Non significant

There was a non-significant relationship between attitude and age $(\mathrm{X} 2=1.59)$, attitude $(\mathrm{X} 2=0.88)$ and sex, attitude and type of family $(\mathrm{X} 2=0.51)$, attitude and $(\mathrm{X} 2=0.35)$, attitude and No. of children $(\mathrm{X} 2=2.32)$, attitude and sex of $\operatorname{child}(\mathrm{X} 2=2.06)$, attitude and education of father $(\mathrm{X} 2=2.82)$, attitude and occupation of father $(\mathrm{X} 2=3.62)$.

Limitations:- The present study was limited to

- Parents of various economic groups from an urban community.

- Minimal number of samples from each economic group

\section{Recommendation:-}

On the basis of the findings of the study it is recommended that

- Similar study can be undertaken with large samples to generalize the findings.

- This study can be extended for children of different age groups.

- This study can be extended for single parent to know how they meet the play needs of their children.

- Experimental study can be conducted with structured teaching programme on knowledge.

- A comparative study can be conducted among parents of urban and rural areas.

- Study can be conducted to find out the practice of parents towards the play needs of children.

- A study can be conducted in hospital settings.

- A comparative study can be conducted to assess the knowledge and attitude among different economic groups.

Projected outcome:- The study will provide adequate knowledge and positive attitude to parents regarding play needs and thereby contributes optimal growth and development for their children of birth to 5 years. 


\section{Conclusion:-}

On the basis of findings of the study the following conclusions were drawn-

The knowledge and attitude regarding play needs of children of birth to 5 years of age group among parents were assessed. Out of 90 samples, 52.2\% samples had inadequate knowledge, 47.3 percent had moderate knowledge and 0 percent had adequate knowledge.38.9 percent had moderately favorable attitude and 61.1 of them favorable attitude. The overall mean of knowledge was 12.10 and standard deviation was 3.5.The overall mean of attitude was 77.62 and standard deviation was 12.3. These findings showed that most of the parents had inadequate knowledge and favorable attitude regarding play needs of children of birth to 5 years of age group

\section{Reference:-}

1. IPA The American Association for the Child's Right to Play. IPA Declaration of a child.5 May.2007. Available from: http://www.ipausa.org/declare.htm (17 Nov.2007).

2. Pollit DF, Hungler BP. Nursing Research Principles and Methods. Philadelphia: J.B.Lippincott Company; 2001

3. Marriner TA. Nursing Theories and their work. Philadelphia: C. V. Mosbee Company; 1989.

4. Best JW. Research in Education.7 ed. New Delhi: Prentice Hall of India Pvt Ltd; 2000.P.105.

5. Marlo RD. Paediatric nursing. 6th ed. Philadelphia: WB Saunders Company; 1998 P.252-4, 738-9, 1018-9, 1131

6. A literature review on play.How to teach Social Studies with Toys. Education Resource Information Centre 23 Nov. 1997. Available from: http://www.eric.ed.gov (17 Nov.2007). 